Vitalina KURYLIAK, Alexander SOKHATSKY

\title{
PRIORITY DIRECTIONS OF NATIONAL SECURITY FINANCING UNDER HYBRID WARFARE CONDITIONS: GLOBAL AND UKRAINIAN CONTEXTS
}

\begin{abstract}
The paper made analysis of the world security situation and confirms the expansion of conflict zones and change in warfare forms.

The main feature of the international confrontation in the $21^{\text {st }}$ century is the use of not only military force but also political, economic, information and other means of non-military character meant by the hybrid warfare concept. The authors singled out the tendency for national security expenses increase and change of priorities in their use. The main shortcomings of the system of national security functioning were identified, the consequence was used by Russia to revenge its influence, invade the territory of Ukraine and occupy the Crimea. The necessity of counteracting the imperial ambitions of Russia in the context of its hybrid warfare set Ukraine the urgent task to create an effective security and defence sector, build up and restructure its military spending.

The paper emphasizes that the priority areas for financing the security and defence sectors in Ukraine are modernization of armaments and military equip-
\end{abstract}

(C) Vitalina Kuryliak, Alexander Sokhatsky, 2018.

Kuryliak Vitalina, Doctor of Economics, Professor, Ternopil National Economic University, Ukraine. Sokhatsky Alexander, Graduate student, Ternopil National Economic University, Ukraine. 
ment, development and procurement of the latest types of weapons, growth of research and development projects in the field of military affairs and related branches like aviation and space.

\section{Key words:}

Hybrid warfare, national security costs, military spending, conflict zones, security and defence sectors, defence budgets, military expenditure structure, defence capabilities.

JEL: H5, O47, C23.

\section{Introduction}

At the end of the twentieth century the world experienced two world wars, a number of armed conflicts and spent 18981.532 billion US dollars on them (2002, p. 15-20), the $21^{\text {st }}$ century was not marked by improvement of the security situation and reduction of military tension. Instead of classical conventional wars and military conflicts, wars of a new type came into play together with military they combine non-military means and lack clearly defined time limits and parties of the conflict. These wars become «the latest type of global confrontation in the current unstable security environment» (Horbulina, 2017, p.16), they create new focal points of tension in all regions of the world. The recent opinion about the impossibility of using the means of the conventional war on the European continent suffered a repulse.

The global confrontation of the present has greatly exacerbated the issue of national security, the definition of a strategy and the effective use of funds for its strengthening in the face of a tense world security situation. For Ukraine, the issue of national security arose particularly acutely after the Russia's annexation of the Crimea in 2014 and expansion of military conflict in the East in April 2015.

At that time, the Ukrainian-Russian war revealed the imperfection and ineffectiveness of the existing system of national security and defence of Ukraine in the aspects of its compliance with modern requirements. However, since 2015 Ukraine has taken sufficiently significant steps towards security sector reforma- 
tion, e.g. adopted a number of conceptual documents at the legislative level, modernized the defence industrial complex, provided and rearmed the Armed Forces, and substantially increased funding for the security sector. At the same time, the issue of determining the size of national security financing and efficiency of its rational use of funds remains relevant.

The above-mentioned makes vital the necessity to study the directions of national security financing the world and NATO in particular; NATO membership is determined by the strategic goal of Ukraine and will give a possibility to formulate the main directions of more effective use of funds for national security in Ukraine.

\section{Analysis of the recent research and publications}

An analysis of the latest research shows that this topic is the subject of attention of a many foreign and Ukrainian researchers. The number of publications dedicatedto clarification of the hybrid war features increased significantly. F. Hoffman (Hoffman, april, 2009) and D. Kilkallen (Kilcullen, 2013) made a research of the essence of hybrid wars, the works of W. Mandragel, O. Bodruk, Yu Mikheev, G. Chernyavsky (Mikheev, 2016) and others determine the causes and nature of contemporary armed conflicts. The issue of the hybrid war essence in the context of the systemic world security crisis, causes and preconditions of Russian aggression against Ukraine and the peculiarities of hybrid warfare in various dimensions have been thoroughly considered by the researchers of the National Institute of Strategic Studies under the guidance of V. Horbulina (Horbulina, 2017).

Funding for national security and its size are largely determined by the state of the economy. Consequently, considerable attention is paid to the role of spending on the national security and the economy. G. Lavrinov, S. Malkov, D. Chernyavsky, A. Shahid, I. Sabaare are among authors worth mentioning. However, a comprehensive analysis of the use of financial resources for national security in the context of hybrid warfare and new security realities in Ukraine was not conducted. 


\section{The aim of the article}

To analyze the dynamics and cost structure for national security in the countries of the world and NATO and make proposals to increase the effectiveness of their formation and use under the hybrid war conditions.

\section{Presentation of the main research material}

The issue of armed conflicts and wars is the global problem which not only failed to find its solution in the $21^{\text {st }}$ century but became even more acute. At the end of the twentieth century the world experienced two world wars, a number of armed conflicts and spent 18981.532 billion US dollars on them (Military expenditures of the world countries, 2002) the $21^{\text {st }}$ century was not marked by the achievement of peace throughout the world.

Based on the data on military expenditures in the countries of the world (Military expenditures of the world countries, 2002), at the beginning of the third millennium, almost 200 armies comprise about 24-25 million people, which is $0.4 \%$ of the world's population. In addition, within 15 years of the $21^{\text {st }}$ century, 17 armed conflicts and conflicts of various kinds broke out (wars in Iraq, Afghanistan, Chechnya, the Russian-Georgian war, conflicts in Macedonia, Southern Serbia, Northern Mali, the Crimea annexation by Russia and the war in the East of Ukraine, Russia's intervention in Syria, etc.).

An essential feature of current military conflicts is mainly domestic or intrastate character. According to experts' opinion, in 1990-2004i.e. during the period of the end of the Cold War, only 4 out of 57 conflicts were interstate: Eritrea Ethiopia (1998 - 2000), India - Pakistan (1990-1992 and 1996 - 2003), Iraq, Kuwait (1991), Iraq vs. the USA, Great Britain and Australia (2003). However, they often extend over much larger territories. Under the conditions of globalization, rapid development of information technology and growing interdependence of world community members, there exists a tendency to involve certain countries or parts of the territory in conflicts (Ingushetia and Dagestan in the conflict between Russia and Chechnya, Macedonia in the conflict between Yugoslavia and NATO in Kosovo). The latter results in the expansion of the conflict zone and transformation of the internal conflict into an interstate with a high degree of confrontation.

The term hybrid warfare, which has no unambiguous interpretation, is most commonly used to describe contemporary conflicts in global and regional aspects. This concept is believed to be used for the first time by the American mili- 
tary theorist $F$. Hoffman to characterize the new military reality. He noted that «... the war of the modern era is characterized by the process of hybridization, within which traditional forms of war, cyber-warfare, organized crime, irregular conflicts, terrorism, etc. are blended» (Hoffman, april, 2009). The basis for F. Hoffman's interpretation of hybrid warfare is the idea of convergence or mutual penetration of various components of the war, application of both kinetic and non-kinetic weapons, involvement of combatants and non- combatants in military conflicts.

Further studies of the essence of the hybrid warfare expanded this concept. Thus, the researchers of the National Institute for Strategic Studies analysed the features of hybrid warfare, made a typology of military conflicts and defined them as «a simultaneous and adaptive application of the closely-integrated set of conventional arms, irregular technology, terrorism, criminal acts, and nonmilitary instruments» (Horbulina, p. 27). At the same time, it is worth to note the fact that the term hybrid warfare is an umbrella term that covers various aspects of this phenomenon and enables integration and a relatively holistic understanding of a wide range of related and diverse approaches «(Horbulina, p. 22).

Therefore, we can argue that the hybrid warfare is an asymmetric war of a new generation, which presupposes usage of both classical way of its conduct and non-lethal instruments, as well as non-state actors - militants and local population groups.

Currently, strengthening of hybrid aggression encourages countries to increase spending on national security and defence. Table 1 presents military expenditures of the world leading countries from 2006 to 2016.

According to the table, all 15 leading world countries forged their military capacities with different pace every year.

Experts estimate that in the 1990s due to the end of the Cold War, the world observed a certain reduction of military spending. However, since 1999 a new wave of its growth has emerged. According to the Stockholm International Peace Research Institute (SIPRI), at the beginning of 2011, military spending reached its peak of 1.73 trillion US dollars in constant figures accounting for $2.5 \%$ of the world GDP.

During the period of 1998-2010, the total world military expenses increased annually; beginning with 2011 , due to the global financial and economic crisis, their growth stalled because the governments of most countries involved in the crisis faced a need for the priority solution of socio-economic problems.

We have to mention that the growth of spending in the context of regions and countries was extremely uneven by 2014 . Therefore, if in $2002-200873 \%$ of the world's countries increased their military spending, in 2008-2011 these countries constituted $56 \%$. In 2011, 10 countries with the largest military budgets accounted for more than $74 \%$ of world expenses. 
Table 1

Military Spending of the Leading Countries in billion dollars

\begin{tabular}{|c|c|c|c|c|c|c|c|c|c|c|c|c|}
\hline & ountry & 2006 & 2007 & 2008 & 2009 & 2010 & 2011 & 2012 & 2013 & 2014 & 2015 & 2016 \\
\hline 1. & USA & 522,7 & 557,0 & \begin{tabular}{|l|l}
621,1 \\
\end{tabular} & 668,6 & 698,2 & 711,3 & 684,8 & 639,7 & 609,9 & 596,0 & 611,0 \\
\hline 2. & RC & 5,3 & 68,1 & 86,4 & 05,6 & 15,7 & 138,0 & 157,5 & 177,9 & 199,7 & 14,8 & 150 \\
\hline 3. & $\begin{array}{l}\text { Saudi } \\
\text { Arabia }\end{array}$ & 96 & 35,5 & 38,2 & 13 & 5,2 & 8,5 & 6,5 & 67,0 & 808 & 372 & 3 \\
\hline 4. & Russia & 4,5 & 43,5 & 6,2 & 1,5 & 58,7 & 0,2 & 81,5 & 88,4 & 34,7 & 6,4 & 70,2 \\
\hline 5. & $\begin{array}{l}\text { United } \\
\text { Kingdor }\end{array}$ & 8 & 66,0 & 65,6 & 57,9 & 58,1 & 60,3 &, 5 & 6,9 & 59,2 & 55,5 & 48,3 \\
\hline 6. & dia & 4,0 & 28,3 & 3,0 & 8,7 & 46,1 & 46,9 & 47,2 & 47,4 & 50,9 & 1,3 & 55,9 \\
\hline 7. & France & 54,5 & 60,6 & 66,0 & 6,9 & 61,8 & 64,6 & 60,0 & 62,4 & 63,6 & 50,9 & 55,7 \\
\hline 8. & Japan & 41,6 & 40,5 & 46,4 & 51,5 & 54,7 & 60,8 & 60,0 & 49,0 & 45,9 & 40,9 & 46,1 \\
\hline 9. & ermal & 1 & 42,6 & 1 & 75 & 46,3 & 3,1 & 5 & 45,9 & 1 & 4 & 41,1 \\
\hline 10. & $\begin{array}{l}\text { outh } \\
\text { orea }\end{array}$ & 5 & 27,7 & 26 & 24, & 28,2 & 31,0 & 32,0 & 34,4 & 37,3 & 36,4 & 36,8 \\
\hline & azil &, 4 & 0,5 &, 5 & 5,6 & 4,0 & 36,9 & 34,0 & 32,9 & 32,7 & 24,6 & 23,7 \\
\hline 12. & Italy & 33,4 & 36,0 & ,2 & 38,3 & 36,0 & 38,1 & 33,7 & 33,9 & 31,6 & 23,8 & 27,9 \\
\hline 13. & Austral & 14,2 & 17,2 & 18,6 & 19,0 & 23,2 & 26,6 & 26,2 & 24,8 & 25,8 & 23,6 & 24,6 \\
\hline 14. & OAU & 7,2 & 8,5 & 11,6 & 13, & 17,5 & 19,2 & 19,0 & 23 & 22 & & 22,8 \\
\hline 15. & Israel & 11,4 & 12,0 & 14,1 & 14,0 & 14,6 & 15,4 & 14,7 & 16,9 & 18,1 & 16,1 & 18,0 \\
\hline
\end{tabular}

Source: compiled by the author according to SIPRI data

The largest reduction of military spending was in 2012. It took place in Europe, namely Italy, France, Germany and a number of other countries, as well as in Japan. During this period, the leaders in spending growth were China, India, Saudi Arabia and others. However, since 2013, a gradual increase in global military spending has been observed.

According to the SIPRI report, in 2016, global military spending increased by $0.4 \%$ and accounted for $\$ 1,686$ billion.

The end of the Second World War and the need for world peace and security in were the impetus for the unification of the efforts of the United States and Canada, and the signing of the Washington Treaty of April 4, 1949 which established a common security system based on the Northern Alliance partnership and resulted in the creation of NATO. This alliance was formed in accordance with Article 51 of the Charter of the United Nations; it confirms the inherent right of individual or collective self-defence. The North Atlantic Alliance is an alliance of free nations, united by their determination to maintain their own security based on mutual ensuring with guarantees and stable relations with other states (online resource). 
NATO countries have 946 billion military budgets (2017). The distribution of military expenditures in 2016 for NATO countries according to the ranking in world military spending is presented in Table 2.

Table 2

\section{Defence spending of NATO members}

\begin{tabular}{|c|c|c|c|c|c|}
\hline $\begin{array}{l}\text { World } \\
\text { rating } \\
2016\end{array}$ & Country & $\begin{array}{l}\text { Spending } \\
\text { (billion } \\
\text { dollars) }\end{array}$ & $\begin{array}{c}\text { Spending, } \\
2 \% \text { of } \\
\text { GDP in } \\
2016\end{array}$ & $\begin{array}{l}\text { World } \\
\text { rating } \\
\text { of } 2 \% \\
\text { of GDP }\end{array}$ & $\begin{array}{c}\text { NATO rat- } \\
\text { ing, based } \\
\text { on } 2 \% \\
\text { of GDP }\end{array}$ \\
\hline 1 & USA & 611 & 371 & 1 & 1 \\
\hline 6 & France & 55,7 & 49,1 & 8 & 4 \\
\hline 7 & United Kingdom & 48,3 & 51,9 & 7 & 3 \\
\hline 9 & Germany & 41,1 & 69,0 & 4 & 2 \\
\hline 11 & Italy & 27,9 & 36,8 & 11 & 5 \\
\hline 16 & Canada & 15,2 & 30,5 & 12 & 6 \\
\hline 17 & Spain & 14,9 & 24,7 & 13 & 7 \\
\hline 18 & Turkey & 14,8 & 14,9 & 19 & 9 \\
\hline 25 & Poland & 9,3 & 9,5 & 26 & 10 \\
\hline 26 & Netherlands & 6,0 & 7,5 & 31 & 12 \\
\hline 33 & Norway & 5,0 & 3,9 & 46 & 15 \\
\hline 38 & Greece & 4,1 & 9,3 & 27 & 11 \\
\hline 43 & Belgium & 3,8 & 4,1 & 44 & 14 \\
\hline 45 & Portugal & 3,5 & 6,0 & 34 & 13 \\
\hline 54 & Romania & 2,8 & 3,7 & 48 & 17 \\
\hline 60 & Czech Republic & 2,0 & 3,9 & 47 & 16 \\
\hline 65 & Hungary & 1,3 & 2,5 & 57 & 18 \\
\hline 67 & Slovakia & 1,0 & 1,8 & 62 & 19 \\
\hline 73 & Bulgaria & 0,8 & 1,0 & 70 & 22 \\
\hline 75 & Croatia & 0,7 & 1,0 & 69 & 21 \\
\hline 76 & Lithuania & 0,6 & 0,9 & 77 & 24 \\
\hline 82 & Estonia & 0,5 & 0,5 & 85 & 26 \\
\hline 89 & Latvia & 0,4 & 0,6 & 82 & 25 \\
\hline 90 & Slovenia & 0,4 & 0,9 & 76 & 23 \\
\hline 103 & Luxembourg & 0,3 & 1,2 & 67 & 20 \\
\hline \multirow[t]{3}{*}{117} & Albania & 0,1 & 0,2 & 107 & 27 \\
\hline & NATO Europe & 254 & 320 & & \\
\hline & NATO & 881 & 722 & & \\
\hline
\end{tabular}

Source: compiled by the author. 
In 2016, percentage of European countries in terms of NATO total spending was only $29 \%$. It should be noted that the spending gap between Europe and the United States has been observed since the 1990's after the end of the Cold War, when the Western European allies gained the benefits of a peaceful dividend, i.e. the possibility to reduce defence spending by $25 \%$ in real terms (online resource). Ultimately, this has led to a significant breakthrough in the technological potential of the United States and its Western European allies. Consequently, as of 1999 US spent $\$ 47$ billion on arms purchases annually while the European partners spent 28 billion dollars. Their spending on military research and development accounted for one quarter of the United States expenses (online resource).

The gap widened considerably in 2004 after the enlargement of the EU. The aforementioned prompted the US to require an increase of defence spending from the European partners. At the two latest NATO summits, B. Obama the president of the United States demanded that Europeans increase their defence spending to $2 \%$ of GDP. However, only D. Trump, after he became a president of the United States, outlined new demands for NATO allies and partners. Despite confirming the intention to comply with the commitments to the allies, D. Trump emphasized that he sees his mission «to represent the United States, not the whole world» (online resource), and demanded that NATO troops be equalized.

Given the recent complicated geopolitical situation and the aggressive policy of Russia, Europe increases its defence spending. Thus, in 2016 military spending in Western Europe increased by $2.6 \%$ compared to 2015 . Similar growth is observed in Central Europe, whose spending increased by $2.4 \%$ in 2016. According to SIPRI, the leaders in defence spending increase were Italy with the record increase of $11 \%$ over the past 2015 and 2016 .

Also, growth in spending is observed in other European countries. Thus, according to the Norwegian Defence Minister Franco Bacque-Jensen, Norway is committed to increase its military spending to $2 \%$ of GDP and spends $27 \%$ of the military budget on weapons procurement. Furthermore, 33\% increase is planned. In turn, Canadian Secretary of Defence Rene Fiataro informs about an increase in military allocations to $70 \%$ (online resource). Today, a significant growth in defence spending is observed in the Baltic countries. Since the beginning of the Ukrainian crisis, the procurement of weapons has doubled and will increase by $100 \%$, analysts say. If in 2005 the total defence budget of the countries of the region amounted to 930 million dollars, it will grow to 2.1 billion by 2020 .

In December 14, 2017, to increase the defence capability of European countries, the EU summit launched PESCO, i.e. the Permanent Structural Cooperation of $25 \mathrm{EU}$ member states in the defence sector. PESCO represents majority of EU countries, except Great Britain, Denmark and Malta. It resulted in 20 obligations on the increase of defence budgets in real terms (to bring defence spending to $2 \%$ of GDP by 2024), participation in joint projects like creation of a common platform of armoured infantry vehicles and formation of the European Medical Command. The main idea of PESCO is to increase defence efficiency, 
eliminate duplication of specific functions performance, and more efficient use of funds. In order to overcome technological gaps in the defence sector, the European Parliament also voted to establish the European Defence Industrial Development Programme (EDIDP) with a budget of $€ 500$ million. The EDIDP will finance the development phase (between research and production) of new and upgraded defence products and technologies in the EU which encompass remotely piloted systems, satellite communications, autonomous space access and permanent earth observation, energy sustainability, cyber and marine safety (online resource).

According to international expert organizations reviews of the defence budget-planning sector, 2018 and subsequent years will demonstrate further economy militarization course. According to IHS by Jane's Markit (the British analyst company) forecasts, world defence spending is expected to reach the highest level in 2018 and will overtake the Cold War record. The HIS analysis, published in the annual review of Jane's Defence Budget, showed that plans for 2018 world defence spending is $3.3 \%$ higher than in 2017. Growth rates will be the highest and the sum will be the largest since the end of the Cold War. Thus, costs increase is included into the budget of the USA, the country with the largest defence budget. The budget for 2018 provides the allocation of $\$ 700$ billion for defence, which is $\$ 26.1$ billion more than the official request of the president. It is peculiar that this is the first time that the budget has a separate article to counteract the Russian threat with 4.6 billion dollars allocation to oppose the Russian aggression within the European containment initiative to support NATO allies and strengthen the US defence capabilities in Europe. In addition, an increase in funds for missile defence, shipbuilding, and space systems is anticipated.

In the context of escalation around the DPRK, Japan also planned to fuel its defence budget by $1.3 \%$ compared to 2017 to a record high of 5.19 trillion yen ( $\$ 48$ billion). Security destabilization on the Korean peninsula compels the AsiaPacific region countries to increase their military spending. Thus, the National Assembly of South Korea, in response to the growth of nuclear and missile threat from North Korea, increased it in 2018 by $7 \%$ compared to 2017 which amounted to $\$ 39.7$ billion.

According to Jane's IHS Markit, in 2018, China's military spending will increase by 6 percent and reach $\$ 203.3$ billion. In recent years, Beijing has been expanding the capabilities of the armed forces and increasing its developments of warships, stealth combat airplanes, unmanned aerial vehicles, modern missiles, and other weapon systems (online resource).

The ISIL terrorist activities and the exacerbation of the Middle East conflict will increase defense spending in the Middle East. Experts estimate that the Middle East countries will increase their defense budgets in 2018; however, this growth will include the other government expenditures. One of the leaders in the growth is Saudi Arabia. The military expenditures of Israel and Iran are projected to increase as well. 
The region with the highest growth in military spending is Eastern Europe. This is how the countries react on Russia's military actions in Ukraine. Thus, the Baltic States - Latvia, Lithuania and Estonia - expect a doubled increase of defense spending compared to 2014, the year of Russian aggression. Growth in military spending is also expected in Western Europe.

As the analysis shows, in general in 2018 and further there will be a tendency towards the growth of military spending, which is primarily due to the existence of a significant number of military conflicts, their escalation, and the aggressive policies of a number of countries in the geopolitical space.

In the structure plan, the spending is directed primarily at the human military potential (on average, the USA spend $100,000 \$$ for one military officer per year) (Kyrylenko, online resource); maintenance, modernization and development of the land, naval and air forces, especially the development of unmanned aerial vehicles; implementation and development of the strategic missile defense and military space program, which envisages substantial funding for research and development of the latest models and technologies.

NATO distributes military spending in the following proportions: $50 \%$ for retention of armed forces, $30 \%$ for development of armaments and military equipment, and $20 \%$ for the training of armed forces.

Before 2014, Ukraine did not pay much attention to the national security issues. Russian invasion, annexation of Crimea, and escalation of hostilities in the East of Ukraine demonstrated the level of weakness and ineffectiveness of the existing at that time national defense system. The system of mobilization training and mobilization was a modified version of the system of the former Soviet Union (Horbulina, p.186). According to the Prosecutor General of Ukraine Y. Lutsenko, during the period from 2005 till 2014, there were sold out 832 tanks, 232 helicopters, 202 aircrafts, 714 armored personnel carriers, 4930 cars, and 28555 units of missile artillery weapons (online resource).

In the Ukrainian Army of early 2014, experts accounted for 4112 tanks, 400 aircraft units, one submarine and 22 million Ukrainians capable of participating in hostilities (online resource). However, most of the existing weapons and military equipment were morally obsolete. In the arsenals and warehouses, there was a significant amount of weapons that were not suitable for further use. The level of provision of material and technical resources, including fuel and lubricants, was also critical.

The unpreparedness of the Ukrainian army to resist the enemy at the beginning of the war was due to the miscalculations in the formation and implementation of military-technical policy and chronic under-financing of the needs for defense capability. Starting from 2007 and including 2013, the defense expenditures as a percentage of GDP practically dropped annually, reaching only $1 \%$ of GDP in 2013 (see fig. 1). 
Figure 1

Ukraine's defense expenditures in 2007-2014

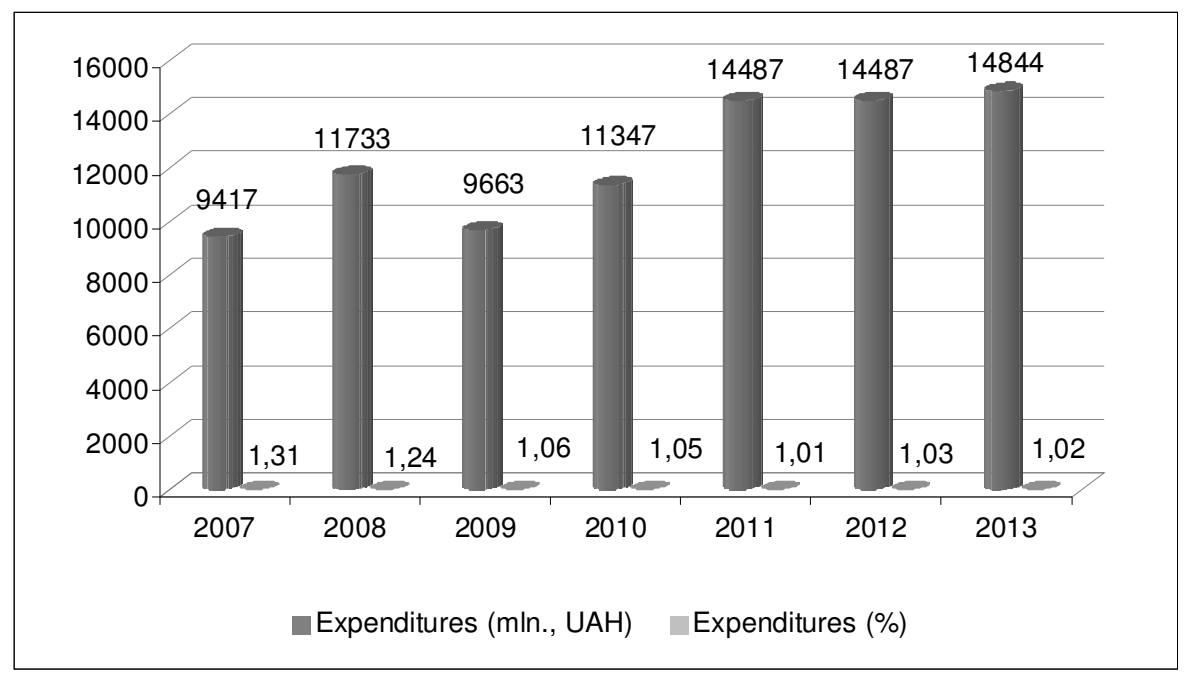

Source: made by the author according to the data (Ministry of Finance of Ukraine, online resource)

In dollar equivalent, the highest decline in the actual funding of defense capabilities of Ukraine was observed in 2009 when the rate of decline was $44.4 \%$ (see Figure 2).

The Russian annexation of Crimea and the occupation of certain districts of Donetsk and Luhansk regions showed the existence of a systemic crisis in the security and defense sector of Ukraine and the need for urgent reform in this sector, including changes in the amount of military expenditures. Beginning in 2015, Ukraine has updated a number of conceptual documents on the new quality of national security. The approach to financing the defense capability of the country radically changed both the amount and the distribution of military expenditures in some articles. State of financing the Armed Forces of Ukraine for the period from 2014 to 2017 is shown in Fig. 3

In 2018, the budget of the Ministry of Defense amounted to 83.3 billion UAH. $(2.56 \%$ of GDP). 
Figure 2

Ukraine's defense expenditures in dollar equivalent in 2007-2014

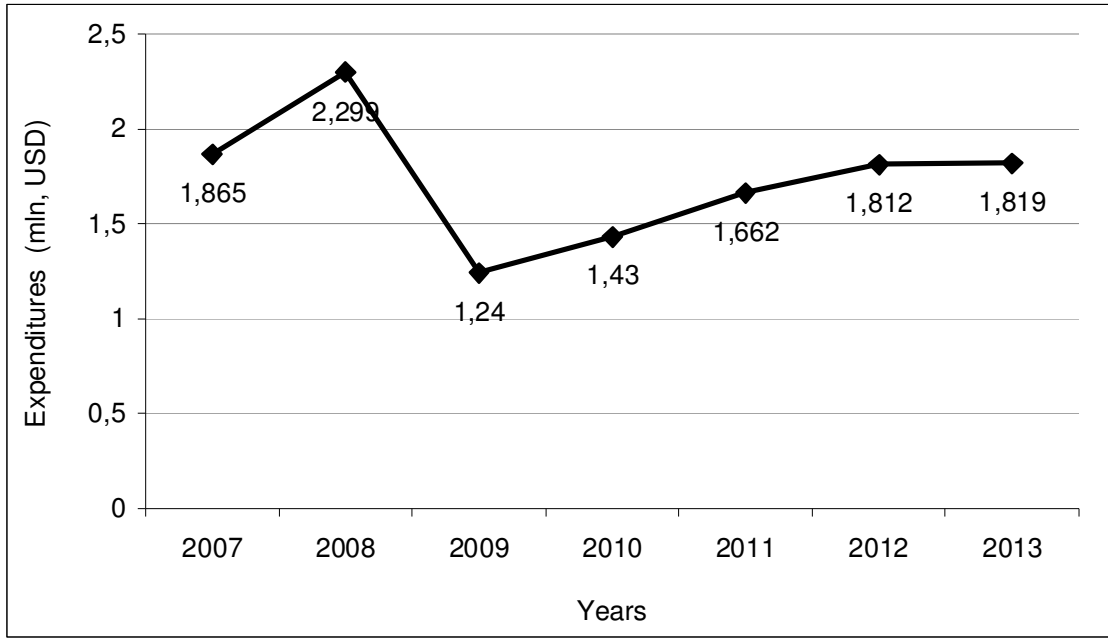

Source: made by the author according to the SIPRI data (Ministry of Finance of Ukraine, online resource)

\section{Figure 3}

\section{Financing of the Ukrainian Armed Forces}

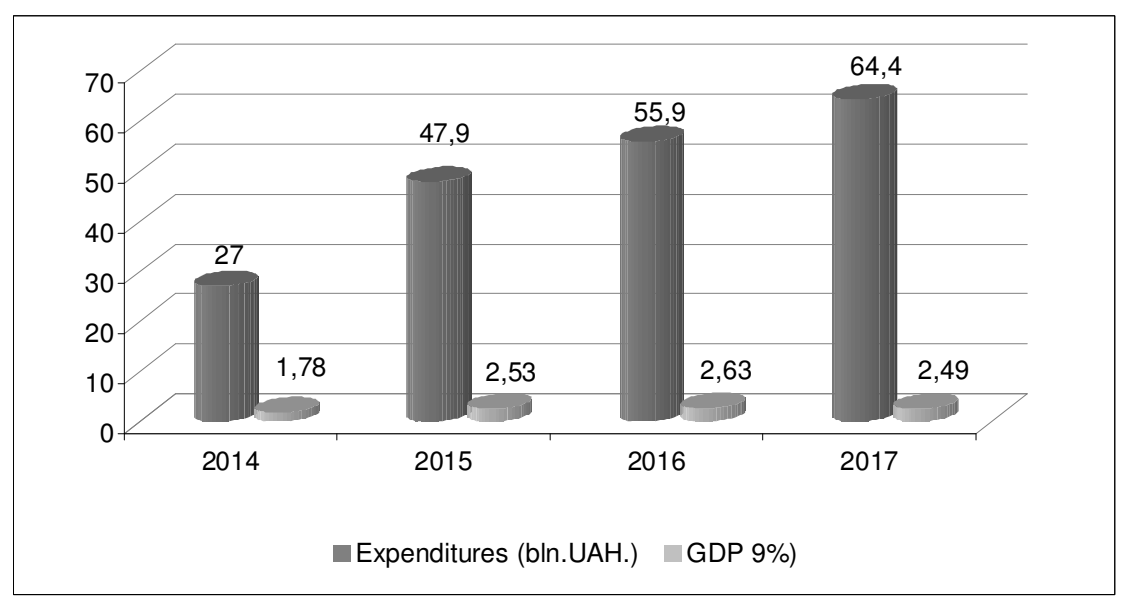

Source: made by the author according to the data (Budget of the Ministry of Defense 2017, online resource) 
During the four years of Russian «hybrid war» against Ukraine, the significant changes in the country's defense capability were realized. The number of the Armed Forces of Ukraine increased to 255 thousand people at the beginning of February 2018. Due to the increased funding, assistance from the West and NATO, the modern Ukrainian army has become well-equipped with modern weapons. Today, the militaries use several variants of modern military uniforms, kevlar helmets with night vision devices, modern unloading vests, CamelBak, high-quality optics, unmanned aerial devices, and the navigation and communication equipment. The armed forces for special operations have also significantly changed. New samples of high quality foreign or modernized Ukrainian models changed the former Soviet samples of weapon. The adoption of a number of important legislative acts has made it possible to significantly improve the Ukrainian defense industry.

Thus, the analysis of military expenditures on the development of armaments and military equipment indicates their growth in comparison to the general growth of military expenditures (Fig. 4). In dollar equivalent, the expenditures increased by more than two times compared with 2013. However, considering the depreciation of equipment, the funds are far from the requirements for ensuring the country's defense capability.

Figure 4

Expenditures on development of armament and military equipment (bln, UAH)

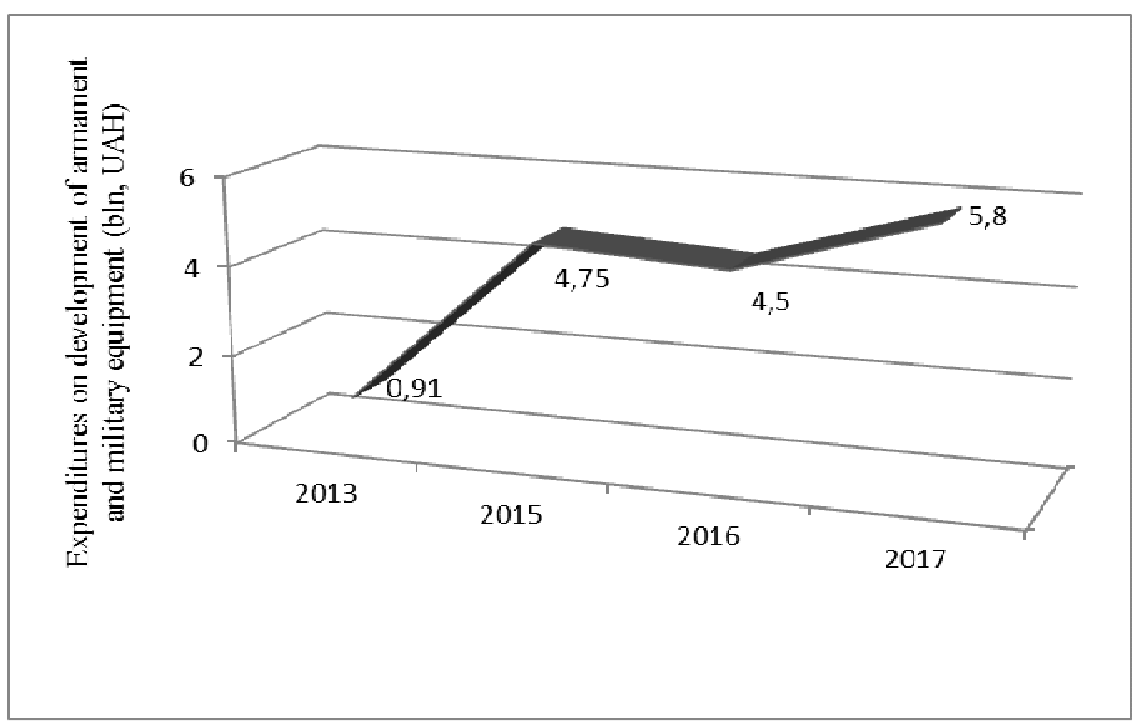

Source: made by the author according to the data (Budget of the Ministry of Defense 2017, online resource) 
The State Budget expenditures include the spending on development of weapons and military equipment, as well as infrastructure improvement and purchase of fuel and lubricants, medical treatment and rehabilitation of the Armed Forces of Ukraine, including members of their families and war veterans. Thus, in 2018 infrastructure expenditures increased by $39.5 \%$ from 3 billion UAH up to 4.2 billion UAH compared to 2017 ; the operating costs increased by $29.5 \%$ from UAH 9.4 billion up to 12.1 billion. The shares of financing the expenditures of the Armed Forces in 2018 are presented in Fig. 5

Figure 5

\section{Financing the Armed Forces}

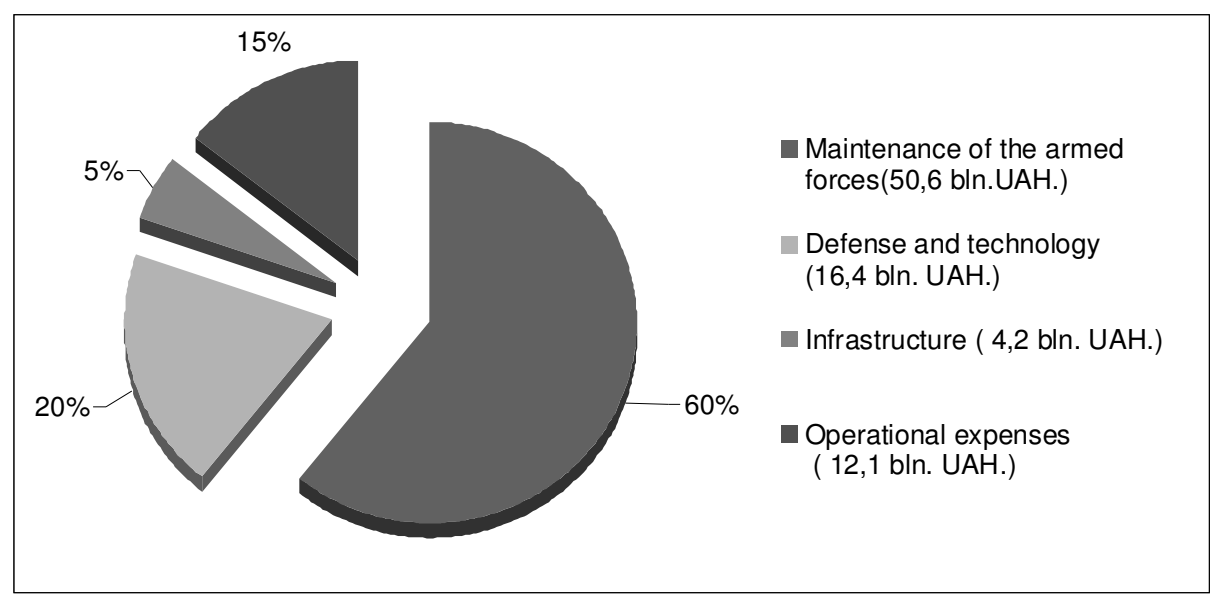

Source: made by the author according to the data (Budget of the Ministry of Defense 2017, online resource)

In 2018, a fairly significant share is given for maintenance of the Armed Forces, which include wages, one-time assistance in the event of death, injury or disability, and food supply of personnel.

Taking into account the tendencies in the financing of the security system of Ukraine in the conditions of the Fourth Industrial Revolution, planning a defense budget, expenditures for research and development of the latest types of equipment and weapons should be increased. According to Klaus Schwab, «the history of warfare and national security is a history of technological progress». It 
is the production of high-tech weapon systems that will not only increase the country's defense capability but will also contribute to improving the macroeconomic indicators such as gross domestic product, employment, the real income of the population, production structure, etc.

It is worth noting that the expenditures for the development of space and aviation industry occupy a significant place in the expenditure structure of the leading countries of the world. The products of these industries have a dual purpose and can be used both in the interests of defense and in the field of commercial use. According to G.A. Lavrinov, during the second half of the twentieth century, the army was the «a doula» for revolutionary changes in technologies such as satellite communications, navigation, jet engines, semiconductors, nuclear energy, space industry, the Internet and others (Military thought, 2007).

Ukraine is recognized in the world as a space state with a significant technological, scientific, and human potential. This gives grounds for asserting the need to increase the level of financing the industry and the products that will not only increase Ukraine's defense capability but also stimulate the further development of science-intensive production.

\section{Conclusions}

The analysis of the national defense financing in the world showed an increase in the expenditures for the security sector, which is caused by the aggravation of military tension. After the end of the Cold War and the establishment of a new world order, the world community again faces the efforts of several countries, first of all of Russia, to redistribute the world and ruin the established world orders. It uses military, psychological, informational, economic, and political methods. Thus, the world community faces the challenge of recognizing and learning how to deal with the new «hybrid» challenges, transforming the structure of spending on national defense in the new conditions.

The intensification of hybrid aggression has prompted the countries of the world to increase military spending today and in the future to keep the course of the militarization of economy. Although the United States, the People's Republic of China, Saudi Arabia, and Russia remain leaders in military spending, there is a significant growth in Western and Central Europe, and the Baltic States due to the difficult geopolitical situation and aggressive Russian politics.

In the structure plan, the expenditures are focused on human military potential and the development of advanced equipment and weapons. A significant share of funds is directed at scientific research that has a positive effect not only on the emergence of new technologies but also on the overall macroeconomic performance of the country. 
If before the Russian invasion of Ukraine there had been a chronic underfunding of the needs of national defense in Ukraine, then from 2015, the approach to financing the defense capability of the country has changed. Now it meets NATO standards. Considering the Russian military aggression, it is expedient for Ukraine to increase spending on the development of new types of weapons and military equipment taking into account the achievements of the Fourth Industrial Revolution, as well as investing in research on the development of high-tech weapon systems.

Space and aviation industry should become an important financing area considering the expenditures of the leading countries of the world and significant technological, scientific, and human potential of these sectors in Ukraine.

\section{References}

1. Military expenditures of the world countries, (2002). Foreign military review, 6. 15-20.

2. Horbulina, V. P. (2017).The World Hybrid War: The Ukrainian Front. Horbulina V. P. (Ed). Kharkiv: Folio, p. 496.

3. Hoffman, F. O. (April. 2009). Hybrid Threats: Reconceptualizing the Evolving Character of Modern Conflict / Frank G. Hoffman// Strategic Forum/ Institute for National Strategic Studies Nation of Defense University. - No. 240. -URL: http://http://www.ndu.edu.inss.

4. Kilcullen, D. (2013). Out of the Mountains: The Coming age of the Urban Guerrilla/ D. Kilcullen. Oxford. University Press, URL:http//www.amazon.com/ Out-Mountains-Coming-Urbanuerrilla/dp/

5. Mikheev. Yu.U. (2016). Definition of the concept «hybrid war». Collection of scientific works of the Military Institute of Kyiv National University named after T. Shevchenko, 51. 124-131 p. URL: http://nbuv.gov.ua/UJRN/Znpviknu _2016_51_18

6. The history of NATO: goals and structure. URL: www./viv.ua/n7/texts/ istorya_stvorennya_NATOhtm

7. URL: http://www.nasledie.ru/oboz/12_03/12_05.HTM

8. URL: http://www.imperativ.net/imp2/7.html

9. Trump's Speech to Congress: Video and Transcript/TheNewYork Times.2017.-Feb.28.

10. US NATO partners responded to Trump's criticism. URL: https://www.ukr.net/\#new

11. The European Parliament supported the defense fund development with a budget of 50 million euro. URL: https://www.ukr.net/\#new 
12. The world trends in the defense industry to expect in 2018. URL: https//defence-ua.com/indexphp/statti/4016-svitivi-tendensiyi-v-oboronniyhaluzi-shcho-ochikuvaty-u-2018-rotsi-2

13. Kyrylenko, O.P. Budget system. URL: https://books. google.com.

14. Ratings of the world armies: how did Ukraine rank in 30th place? URL: https://www. google.com.ua

15. What are the consequences of reducing Ukraine's defense spending? URL: https://www. Depo.ua/ukr/war/ yakinaslidki - matime- skorochennya

16. Ministry of Finance of Ukraine. URL:https://minfin/kmu/gov/ua/news/bjudzhet

17. Budget of the Ministry of Defense $2017: 18 \%$ of funds will be spent on the technical strengthening of the troops, and surcharges will increase up to 6 thousand. URL: namail/gov.ua/43410 na- tehnichne-pidsylennya-viy/

18. The influence of military expenditures on the development of the country's economy (2007). Military thought, 12. 19-24. 